\title{
SISTEM PAKAR DIAGNOSIS PENYAKIT ASMA DENGAN MENGGUNAKAN ALGORITME GENETIK (Studi Kasus RSUD Kabupaten Kepahiang)
}

\author{
Ardi Wijaya ${ }^{1}$, Rozali Toyib ${ }^{2}$ \\ ${ }^{1,2}$ Teknik Informatika, Fakultas Teknik, Universitas Muhammadiyah Bengkulu \\ Jl. Bali Po. Box, 118 Kota Bengkulu 38119 INDONESIA \\ ${ }^{1}$ ardiwijaya009@gmail.com \\ ${ }^{2}$ rozalitoyibegmail.com
}

Abstrak: Asma merupakan gangguan inflamasi kronik pada saluran nafas yang melibatkan banyak sel-sel inflamasi seperti eosinofil, sel mast, leukotrin dan lain-lain. Inflamasi kronik ini berhubungan dengan hiperresponsif jalan nafas yang menimbulkan episode berulang dari mengi (wheezing), sesak nafas, dada terasa berat dan batuk terutama pada malam dan pagi dini hari. Kejadian ini biasanya ditandai dengan obstruksi jalan napas yang bersifat reversible. Penyakit asma bersifat fluktuatif (hilang timbul) artinya dapat tenang tanpa gejala tidak mengganggu aktifitas tetapi dapat eksaserbasi dengan gejala ringan sampai berat bahkan dapat menimbulkan kematian, alternatif dalam mendiagnosis penyakit asma. Sistem pakar dengan menggunakan Algoritme Genetika akan membantu dalam menemukan informasi jenis penyakit asma berdasarkan gejala klinis yang dirasakan sampai ditemukannya kesimpulan berdasarkan hasil diagnosis berupa informasi mengenai cara pengobatan penyakit asma. Pendekatan yang diambil oleh algoritme ini adalah dengan menggabungkan secara acak berbagai pilihan solusi terbaik di dalam suatu kumpulan untuk mendapatkan generasi solusi terbaik berikutnya yaitu pada suatu kondisi yang memaksimalkan kecocokannya atau lazim disebut fitness. Generasi ini akan merepresentasikan perbaikan perbaikan pada populasi awalnya dengan melakukan proses ini secara berulang algoritme ini diharapkan dapat mensimulasikan proses evolusioner pada akhirnya akan didapatkan solusi-solusi yang paling tepat bagi permasalahan yang dihadapi. Berdasarkan hasil pengujian dapat diambilkesimpulan : Dari hasil pengujian sistem diperoleh jawaban sangat menarik $47 \%$, menarik $45 \%$, dan tidak menarik $8 \%$. Durasi waktu proses perhitungan pada algoritme genetika kurang efisien.

Kata Kunci: asma, sesak napas, saluran nafas, algoritme genetika

Abstract: Asthma is a chronic inflammatory disorder of the airways involving many inflammatory cells such as eosinophils, mast cells, leukotrin and others. This chronic inflammation is associated with respiratory hyperresponsiveness that results in recurrent episodes of wheezing, shortness of breath, heavy chest and cough especially in the early morning and early morning. This incidence is usually characterized by reversible airway obstruction, asthma is fluctuating, meaning it can calm without symptoms not interfere with the activity but can exacerbate with mild to severe symptoms can even lead to death, an alternative in diagnosing asthma. Expert system using Genetic Algorithm will help in finding information of type of asthma disease based on clinical symptoms perceived for the found conclusion based on diagnosis result of information about the way of treatment of asthma disease. The approach taken by this algorithm is to combine randomly various choice of best solution in a collection to get the next generation of the next best solution that is in a condition that maximizes its compatibility or commonly called fitness. This generation will represent improvements in improvements in the initial population by doing this process repeatedly this algorithm is expected to simulate the evolutionary process will eventually get the most appropriate solutions to the problems encountered. Based on the results of the test can be taken conclusion: From the results of the system test obtained a very interesting answer $47 \%$, attract $45 \%$, and not draw $8 \%$. Duration of time calculation process on genetic algorithm less efficient.

Keywords: asthma, shortness of breath, breath channels, genetic algorithms 
Jurnal Pseudocode, Volume V Nomor 2, September 2018, ISSN 2355-5920

www.ejournal.unib.ac.id/index.php/pseudocode

\section{Pendahuluan}

Asma merupakan gangguan inflamasi kronik pada saluran nafas yang melibatkan banyak sel-sel inflamasi seperti eosinofil, sel mast, leukotrin dan lain-lain. Inflamasi kronik ini berhubungan dengan hiperresponsif jalan nafas yang menimbulkan episode berulang dari mengi (wheezing), sesak nafas, dada terasa berat dan batuk terutama pada malam dan pagi dini hari. Kejadian ini biasanya ditandai dengan obstruksi jalan napas yang bersifat reversibel baik secara spontan atau dengan pengobatan [1,2]. Asma masih merupakan masalah yang mendunia dengan perkiraan 300 juta orang yang menderitanya. Hal tersebut didasarkan dengan terdapatnya ratusan laporan mengenai prevalensi asma pada populasi-populasi yang berbeda.Berdasarkan data World Health Organization (WHO) pada tahun 2005, jumlah penderita asma di dunia diperkirakan akan terus bertambah sebanyak 180.000 orang setiap tahunnya. Setiap tahunnya di dunia kematian akibat asma diperkirakan mencapai 250.000 orang [1,3]. Di Indonesia berdasarkan Hasil survei RISKESDAS pada tahun 2007 prevalensi asma mencapai 3,5\% dari jumlah seluruh penduduk di Indonesia. Dimana asma menempati sepuluh besar penyebab kesakitan dan kematian di Indonesia. Secara nasional yang tergambar dari data survei kesehatan rumah tangga (SKRT) di berbagai provinsi di Indonesia. Sebanyak 9 provinsi yang mempunyai prevalensi penyakit asma tertinggi antara lain, Aceh diurutan pertama di ikuti Jawa Barat, Nusa Tenggara Barat, Nusa Tenggara Timur, Kalimantan Selatan, Sulawesi Tengah, Sulawesi Tenggara, Gorontalo dan Papua Barat.

Menurut Departemen Kesehatan RI penyakit asma adalah suatu kelainan berupa inflamasi (peradangan) kronik saluran nafas yang menyebabkan hipereaktivitas bronkus terhadap berbagai rangsangan yang ditandai dengan gejala episodik berulang berupa batuk,sesak nafas dan rasa berat di dada terutama pada malam atau dini hari yang umumnya bersifat reversible baik dengan atau tanpa pengobatan. Penyakit asma bersifat fluktuatif (hilang timbul) artinya dapat tenang tanpa gejala tidak mengganggu aktifitas tetapi dapat eksaserbasi dengan gejala ringan sampai berat bahkan dapat menimbulkan kematian [1].

Berbagai upaya telah dilakukan oleh pemerintah untuk menanggulangi penyakit asma di masyarakat seperti bimbingan teknis, pemantauan, penyuluhan dibidang penyakit asma. Oleh sebab itu, dirasakan perlu dibuat sebuah aplikasi yang dapat membantu proses penyuluhan kepada masyarakat untuk menanggulangi penyakit asma yang berbentuk aplika siperangkat lunak yang dapat bekerja sebagai mana halnya dokter ahli bekerja sebagai alternatif dalam mendiagnosis penyakit asma.

Sistem pakar dengan menggunakan algoritme Genetika akan membantu dalam menemukan informasi jenis penyakit asma berdasarkan gejala klinis yang dirasakan sampai ditemukannya kesimpulan berdasarkan hasil diagnosis berupa informasi mengenai cara pengobatan penyakit asma. Pendekatan yang diambil oleh algoritme ini adalah dengan menggabungkan secara acak berbagai pilihan solusi terbaik di dalam suatu kumpulan untuk mendapatkan generasi solusi terbaik berikutnya yaitu pada suatu kondisi yang memaksimalkan kecocokannya atau lazim disebut fitness. Generasi ini akan merepresentasikan perbaikan perbaikan pada populasi awalnya dengan melakukan proses ini secara berulang algoritme ini diharapkan dapat mensimulasikan 
Jurnal Pseudocode, Volume V Nomor 2, September 2018, ISSN 2355-5920

www.ejournal.unib.ac.id/index.php/pseudocode

proses evolusioner pada akhirnya akan didapatkan solusi-solusi yang paling tepat bagi permasalahan yang dihadapi [2].

\section{LANDASAN TEORI}

\section{A. Sistem Pakar}

Sistem Pakar adalah suatu program komputer yang dirancang untuk memodelkan kemampuan penyelesaian masalah yang dilakukan oleh seorang pakar berbasis komputer yang digunakan untuk menyelesaikan masalah sebagaimana yang dipikirkan oleh pakar. Pakar yang dimaksud disini adalah orang yang mempunyai keahlian khusus yang dapat menyelesaikan masalah yang tidak dapat diselesaikan oleh orang awam. Sebagai contoh, dokter adalah seorang pakar yang mampu mendiagnosis penyakit yang diderita pasien serta dapat memberikan penatalaksanaan terhadap penyakit tersebut.

Sistem pakar adalah program artificial intellegence yang menggabungkan pangkalan pengetahuan (Knowledge Base) dengan sistem inferensi, ini merupakan bagian software spesialisasi tingkat tinggi yang berusaha menduplikasi fungsi seorang pakar dalam satu bidang keahlian. Program ini bertindak sebagai seorang konsultan yang cerdas atau penasihat dalam suatu lingkungan keahlian tertentu, sebagai hasil himpunan pengetahuan yang telah dikumpulkan dari beberapa orang pakar dengan demikian seorang awam sekalipun bisa menyadap sistem pakar itu untuk memecahkan berbagai persoalan yang ia hadapi, sistem pakar merupakan sesuatu yang baru dan masih segar ia sangat inovatif dalam menghimpun dan mengemas pengetahuan, keampuhannya yang paling utama terletak pada kemampuan dan penggunaan praktisnya bila di satu tempat tidak ada seorang pakar dalam suatu bidang ilmu [3].

\section{B. Diagnosis}

Masalah penting pada morbiditas asma.adalah kemampuan untuk mendiagnosis dan seperti telah kita ketahui bahwa diagnosis asma pada anak tidak selalu mudah untuk ditegakkan. Beberapa kriteria diagnosis untuk itu selalu mempunyai berbagai kelemahan, tetapi umumnyadisepakati bahwa hiper reaktivitas bronkus tetap merupakan bukti objektif yang perlu untuk diagnosis asma, termasuk untuk asma pada anak.

Gejala klinis utama asma anak pada umumnya adalah mengi berulang dan sesak napas, tetapi pada anak tidak jarang batuk kronik dapat merupakan satu-satunya gejala klinis yang ditemukan. Biasanya batuk kronik itu berhubungan dengan infeksi saluran napas atas, selain itu harus dipikirkan pula kemungkinan asma pada anak bila terdapat penurunan kosentrasi terhadap aktivitas fisik atau gejala batuk malam hari [4].

\section{Penyakit Asma}

Asma merupakan penyakit kronik tersering padaanak dan masih tetap merupakan masalah bagi pasien, keluarga, dan bahkan para klinisi dan peneliti asma.Mengacu padadata epidemiologi Amerika Serikat pada saat ini diperkirakan terdapat $4-7 \%$ (4,8 juta anak) dari seluruh populasi asma. Selain karena jumlahnya yang banyak, pasien asma anak dapat terdiri dari bayi, anak, dan remaja, serta mempunyai permasalahan masingmasing dengan implikasi khusus pada piñata laksanaannya. Pengetahuan dasar tentang masalah sensitisasi alergi dan inflamasik hususnya, telah banyak mengubah sikap kita terhadap pengobatan 
Jurnal Pseudocode, Volume V Nomor 2, September 2018, ISSN 2355-5920

www.ejournal.unib.ac.id/index.php/pseudocode

asma anak, terutama tentang perananti-inflamasi sebagai salah satu dasar pengobatan asma anak. Oleh karena itu pengertian yang lebih baik tentang peran faktor genetik, sensitisasi dini oleh allergen dan polutan,infeksi virus,serta masalah lingkungan sosial, ekonomi danp sikologi anak dengan asmadiharapkan dapat membawa perbaikan dalam penata laksanaan asma. Ada dua jenis pemicu penyakit asma, yaitu alergen dan iritan.

Alergen adalah zat yang menyebabkan gejala penyakit asma dengan cara memunculkan reaksi alergi. Alergen penyakit asma yang umum di antaranya: serbuk sari (bunga), hewan, dan tungau debu rumah. Iritan adalah zat yang menyebabkan gejala penyakit asma dengan cara mengganggu saluran pernapasan. Iritan penyakit asma yang umum di antaranya: udara dingin, asap rokok, dan asap sisa pembakaran bahan kimia.

Ada 3 klasifikasi penyakit asma, yaitu: berdasarkan waktu (terdiri dari penyakit asma akut, penyakit asma kronis, dan penyakit asma periodik), berdasarkan penyebab (terdiri dari penyakit asma ekstrinsik, dan penyakit asma intrinsik), berdasarkan berat/ringan gejala (terdiri dari penyakit asma berat, penyakit asma sedang, dan penyakit asma ringan). Selain itu, menurut Bull (2005: 10) ada 3 tipe penyakit asma, diantaranya: penyakit asma pekerjaan, penyakit asma sensitif aspirin, dan penyakit asma yang dipicu olahraga.

\section{a. Asma Mengi}

Sebagian besar (Sari Pediatri, 2002: 79) manifestasi akan muncul sebelum usia 6 tahun dan kebanyakan gejala awal sudah ditemukan pada masa bayi,berupa mengiberulang atau tanpa batuk yang berhubungan dengan infeksi virus. Hubungan antara semasa bayi dengan kejadian asma pada masa kehidupan selanjutnya telah banyak dibahas, para peneliti umumnya melaporkan bahwa hanya sebagian kecil saja (3-10\%) dari kelompok bayi yang berhubungan dengan infeksiviru stersebut akan memperlihatkan progressivitas klinis menjadi asma bronkial. Infeksi virus semasa bayi yang menimbulkan bronkiolitis dengan gejala terutama disebabkan oleh viruss insitialre spiratori (RSV), virus parainfluenza, dan adenovirus.

Kecenderungan bayi menjadi asma sangat ditentukan oleh faktor genetik atopi. Sebagian besar bayi tersebut jelas mempunyai riwayat keluarga serta menunjukkan positivitas, dibandingkan dengan bayi yang tidak menderita asma. Kemampuan bayi untuk membentuk lgeanti RSV ini diyakini sebagai status sensitisasi terhadap alergen secara umum.

b. Asma Potogenesis

Patogenesis asma (Dahlan, 2000: Nurrachma Yuliasri, 2010: 7) merupakan penyakit paru dengan karakteristik inflamasi saluran napas, hiperraktivitas saluran napas terhadap berbagai rangsangan distruksi saluran napas yang resibel baik secara spontan maupun dengan pengobatan.

Inflamasi kronik asma mengaktifkan berbagai sel inflamasi. Sel inflamasi yang ikut berperan terutama sel mast, eosinofil, sel limfosit, makrofag neutrofil dan sel epithel (PDPI, 2004: Nurrachma Yuliasri, 2010: 7). Sel-sel inflamasi yang diaktifkan melepas berbagai mediator, sitrokin, molekul adhesi, kemokin, dan berinteraksi antara satu dengan yang lain.

c. Asma Sentitasi

Sensitisasi asma (Sari Pediatri, 2002: 79) merupakan hubungan antara proses sensitisasi alergi dengan perkembangan dan perjalanan penyakit alergi yang dikenal sebagai allergic march (perjalanan alamiah penyakit alergi). Secara klinis allergic march terlihat berawal sebagai 
Jurnal Pseudocode, Volume V Nomor 2, September 2018, ISSN 2355-5920 www.ejournal.unib.ac.id/index.php/pseudocode

alergi saluran cerna (diare alergi susu sapi) yang akan berkembang menjadi alergi kulit (dermatitis atopi) dan kemudian alergi saluran napas (asma bronkial, rinitis alergi).

Suatu penelitian memperlihatkan bahwa kelompok anak dengan gejala mengi pada usia kurang dari 3 tahun, yang menetap sampai usia 6 tahun, mempunyai predisposisi ibu asma, dermatitis atopi, rinitis alergi, dan peningkatan kadar $\operatorname{lgE}$, dibandingkan dengan kelompok anak dengan mengi yang tidak menetap.

\section{Algoritme Genetik}

Algoritme ini ditemukan di Universitas Michigan, Amerika Serikat oleh John Holland (1975) melalui sebuah penelitian dan dipopulerkan oleh salah satu muridnya, David Goldberg. Algoritme genetik adalah algoritme yang berusaha menerapkan pemahaman mengenai evolusi alamiah pada tugas-tugas pemecahan-masalah (problem solving). Pendekatan yang diambil oleh algoritme ini adalah dengan menggabungkan secara acak berbagai pilihan solusi terbaik di dalam suatu kumpulan untuk mendapatkan generasi solusi terbaik berikutnya yaitu pada suatu kondisi yang memaksimalkan kecocokannya atau lazim disebut fitness.

Generasi ini akan merepresentasikan perbaikan - perbaikan pada populasi awalnya. Dengan melakukan proses ini secara berulang, algoritme ini diharapkan dapat mensimulasikan proses evolusioner. Pada akhirnya, akan didapatkan solusi-solusi yang paling tepat bagi permasalahan yang dihadapi. Untuk menggunakan algoritme genetik, solusi permasalahan direpresentasikan sebagai kromosom. Tiga aspek yang pentinguntuk penggunaan algoritme genetik:

\section{Definisi fitness function}

2. Definisi dan implementasi representasi genetik

3. Definisi dan implementasi operasi genetik

Jika ketiga aspek di atas telah didefinisikan, algoritme genetik generik akan bekerja dengan baik. Tentu saja, algoritme genetik bukanlah solusi terbaik untuk memecahkan segala masalah. Sebagai contoh, metode tradisional telah diatur untuk untuk mencari penyelesaian dari fungsi analitis convex yang "berperilaku baik" yang variabelnya sedikit. Pada kasus ini, metode berbasis kalkulus lebih unggul dari algoritme genetik karena metode ini dengan cepat menemukan solusi minimum ketika algoritme genetik masih menganalisa bobot dari populasi awal.

Untuk problem - problem ini pengguna harus mengakui fakta dari pengalaman ini dan memakai metode tradisional yang lebih cepat tersebut. Akan tetapi, banyak persoalan realistis yang berada di luar golongan ini. Selain itu, untuk persoalan yang tidak terlalu rumit, banyak cara yang lebih cepat dari algoritme genetik. Jumlah besar dari populasi solusi, yang merupakan keunggulan dari algoritme genetik, juga harus mengakui kekurangannya dalam kecepatan pada sekumpulan komputer yang dipasang secara seri -fitness function dari tiap solusi harus dievaluasi.

Namun, bila tersedia komputer-komputer yang paralel, tiap prosesor dapat mengevaluasi fungsi yang terpisah pada saat yang bersamaan. Karena itulah, algoritme genetik sangat cocok untuk perhitungan yang paralel. Algoritme adalah susunan langkah-langkah sistematis dan logis dalam pemecahan suatu masalah. Algoritme berasal dari nama seorang ahli matematika bangsa arab yaitu Abu Ja'far Muhammad Ibnu Musa Al- 
Jurnal Pseudocode, Volume V Nomor 2, September 2018, ISSN 2355-5920

www.ejournal.unib.ac.id/index.php/pseudocode

Khuwarizmi.

Al-Khuwarizmi dibaca oleh orang barat menjadi Algorism. Perubahan kata algorism menjadi algorithm karena kata algorism sering dikelirukan dengan arithmetic, sehingga akhiran sm berubah menjadi thm, lambat laun kata algorithm dipakai menjadi metode perhitungan (komputasi) secara umum, sehingga kehilangan makna aslinya. Dalam bahasa indonesia kata algorithm diartikan menjadi algoritme.

Genetika merupakan genetik Gen dan Kromosom yang berhubungan dengan DNA, RNA, Polipeptida dalam Sintesis Protein Reproduksi Sel (mitosis dan meiosis), Pewarisan Sifat pada makhluk Hidup, Penentuan Jenis Kelamin dan Mutasi [6].

Algoritme Genetik adalah suatu algoritme pencarian berdasarkan pada mekanisme seleksi alam dan genetika alam. Algoritme genetika dimulai dengan sekumpulan solusi awal (individu) yang disebut populasi. Satu hal yang sangat penting adalah bahwa satu individu menyatakan satu solusi. Populasi awal akan berevolusi menjadi populasi baru melalui serangkaian iterasi (generasi). Menurut pada akhir iterasi,algoritme genetika mengembalikan satu anggota populasi yang terbaik sebagai solusi untuk masalah yang dihadapi.

\section{METODE PENELITIAN}

\section{A. Tempat dan Waktu Penelitian}

Penulis melakukan penelitan di Rumah Sakit Umum Daerah (RSUD) Kab.Kepahiang yang dilaksanakan selama 1 (satu) bulan.

\section{B. Analisis Sistem}

Analisis sistem yang dilakukan dalam pembuatan sistem pakar diagnosis penyakit asma ini adalah mengidentifikasi gejala-gejala penyakit asma, kemudian dirancang sebuah sistem pakar yang dapat mendiagnosis penyakit asma, sehingga dapat mengatasi penyakit tersebut. Berikut pengkodean, jenis penyakit, gejala, obat, dan solusi terhadap penyakit asma:

\section{Jenis Penyakit Asma}

Adapun pengkodean jenis penyakit asma yang dibuat dalam tabel berikut:

Tabel 1. Kode Jenis Penyakit Asma

\begin{tabular}{|l|l|}
\hline Kode & \multicolumn{1}{|c|}{ Nama Penyakit Asma } \\
\hline Pp1 & Asma Mengi \\
\hline Pp2 & Asma Patogenesis \\
\hline Pp3 & Asma Sensitisasi \\
\hline
\end{tabular}

2. Gejala Penyakit Asma

Adapun pengkodean gejala penyakit asma yang dibuat dalam tabel berikut yaitu:

Tabel 2. Kode Gejala Penyakit Asma

\begin{tabular}{|c|l|}
\hline Kode & \multicolumn{1}{|c|}{ Gejala Penyakit Asma } \\
\hline Gp1 & $\begin{array}{l}\text { Dada terasa seperti terhimpit, semakin berat } \\
\text { dan sering }\end{array}$ \\
\hline Gp2 & Jantung berdebar \\
\hline Gp3 & Jari atau bibir anak membiru \\
\hline Gp4 & $\begin{array}{l}\text { Bronkitis yang terjadi berulang-ulang kali (sering } \\
\text { kambuh) }\end{array}$ \\
\hline Gp5 & Kejang - kejang \\
\hline Gp6 & Sulit bernafas \\
\hline Gp7 & Muncul bunyi saat bernafas \\
\hline Gp8 & $\begin{array}{l}\text { Batuk yang bersifat menetap atau tak kunjung } \\
\text { sembuh }\end{array}$ \\
\hline Gp9 & $\begin{array}{l}\text { Saat beraktivitas, anak tampak kurang bertenaga, } \\
\text { mudah lemas }\end{array}$ \\
\hline Gp10 & $\begin{array}{l}\text { Retraksi atau dada bergerak naik turun ketika } \\
\text { bernafas }\end{array}$ \\
\hline Gp11 & Si kecil sering merasakan sesak di dada \\
\hline Gp12 & $\begin{array}{l}\text { Napas terengah-engah dan cepat membuat anak } \\
\text { bicara dengan terbata-bata }\end{array}$ \\
\hline Gp13 & Mual muntah pada anak \\
\hline Gp14 & Demam tinggi pada anak \\
\hline Gp15 & Gemetaran pada tubuh anak \\
\hline
\end{tabular}

3. Obat Penyakit Asma

Adapun solusi pengobatan penderita penyakit asma yaitu:

Tabel 3. Obatan Penyakit Asma

\begin{tabular}{|c|l|}
\hline Kode & \multicolumn{1}{|c|}{ Obat Penyakit Asma } \\
\hline Op1 & Bronchodilator \\
\hline Op2 & Kostikosteroid hirup \\
\hline Op3 & Beta Antagonis \\
\hline Op4 & reseptor Leukotriene \\
\hline Op5 & Albuterol \\
\hline
\end{tabular}


Jurnal Pseudocode, Volume V Nomor 2, September 2018, ISSN 2355-5920

www.ejournal.unib.ac.id/index.php/pseudocode

4. Solusi Penyakit Asma

Adapun kode solusi agar tehindar penyakit asma pada anak sebagai berikut:

Tabel 4. Kode Solusi Penyakit Asma

\begin{tabular}{|c|}
\hline Kode Solusi Penyakit Asma \\
\hline $\mathrm{Sp} 1$ \\
\hline
\end{tabular}

5. Rule

Adapun rule sistem pakar penyakit asma dapat dilihat pada tabel berikut ini:

Tabel 5. Rule Penyakit Asma

\begin{tabular}{|c|c|c|c|c|}
\hline $\begin{array}{l}\text { Kode } \\
\text { Rule }\end{array}$ & $\begin{array}{c}\text { Gejala } \\
\text { Penyakit }\end{array}$ & $\begin{array}{c}\text { Nama } \\
\text { Penyakit }\end{array}$ & $\begin{array}{c}\text { Solusi } \\
\text { Penyakit }\end{array}$ & $\begin{array}{c}\text { Obat } \\
\text { Penyakit }\end{array}$ \\
\hline R1 & $\begin{array}{c}\text { Gp1,Gp2, } \\
\text { Gp3, } \\
\text { Gp4,Gp5 }\end{array}$ & $\begin{array}{l}\text { Asma } \\
\text { Mengi }\end{array}$ & Sp1 & $\begin{array}{l}\text { Op1, } \\
\text { Op2, Op3 }\end{array}$ \\
\hline $\mathrm{R} 2$ & $\begin{array}{c}\text { Gp6,Gp7, } \\
\text { Gp8, } \\
\text { Gp9, } \\
\text { Gp10 }\end{array}$ & $\begin{array}{c}\text { Asma } \\
\text { Patogene } \\
\text { sis }\end{array}$ & Sp1 & $\begin{array}{l}\text { Op1, } \\
\text { Op2, } \\
\text { Op5, Op3 }\end{array}$ \\
\hline R3 & $\begin{array}{c}\text { Gp11,Gp } \\
12, \\
\text { Gp13, } \\
\text { Gp14, } \\
\text { Gp15 }\end{array}$ & $\begin{array}{c}\text { Asma } \\
\text { Sentisasi }\end{array}$ & Sp1 & $\begin{array}{l}\text { Op1, } \\
\text { Op6, } \\
\text { Op2, Op4 }\end{array}$ \\
\hline
\end{tabular}

C. Pemodelan Sistem

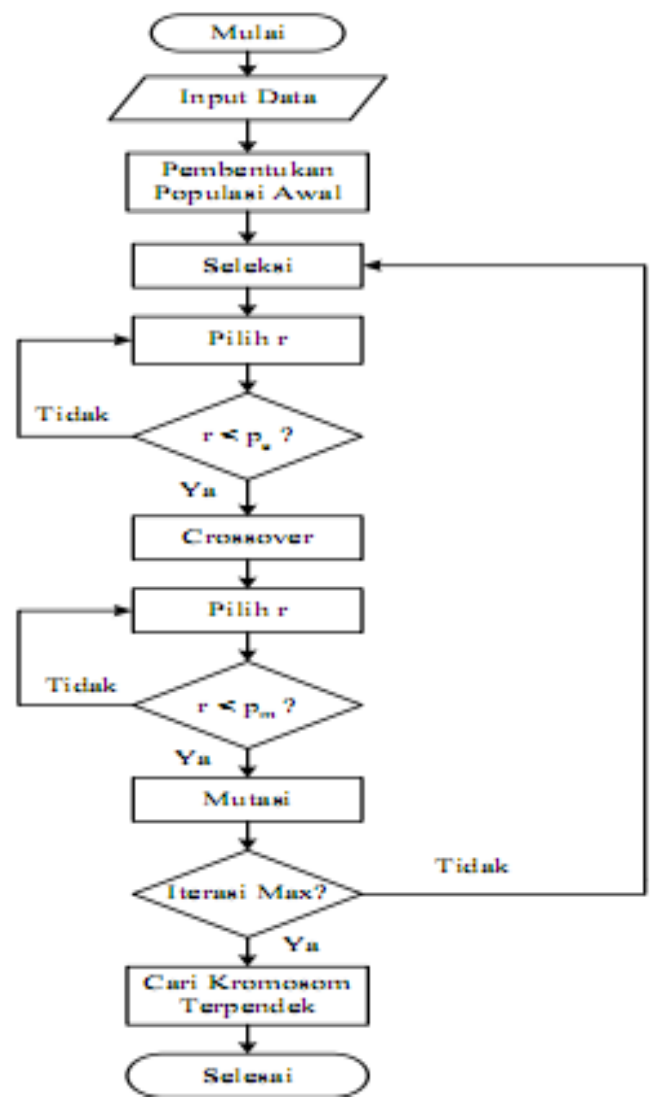

Gambar 1. Flowchart Algoritme Genetika
Adapun langkah-langkah perhitungan menggunakan metode algoritme genetik adalah karena yang dicari adalah nilai a, b, c, d, e maka variable a, b, c, d, e dijadikan sebagai gen-gen pembentuk chromosome. Batasan nilai variabel a adalah bilangan integer 0 sampai 30. Sedangkan batasan nilaivariabel b, c, d, dan e adalah bilangan integer 0 sampai 10 sebagai berikut:

a. Menentukan nilai hasil diagnosis

Nilai hasil diagnosis oleh pakar yang didapatkan dari hasil wawancara dari pasien. Karena kita ingin mencari nilai optimal dari gejalagejala tersebut maka, dijadikan gen pembentuk kromosom. Berikut contoh penyelesaiannya:

Fungsi_objektif (chromosome) = $(a+2 b+3 c+4 d+e)-30 \mid$ kita hitung fungsi_objektif dari chromosome yang telah dibangkitkan:

Chromosome [1]= Gp1

Chromosome [2]= Gp2

Chromosome [3]= Gp3

Chromosome [4]= Gp4

Chromosome [5]= Gp5

Chromosome [6]= Gp6

b. Inisialisasi

Chromosome[1] $=[\mathrm{a} ; \mathrm{b} ; \mathrm{c} ; \mathrm{d}]=[15 ; 04 ; 06 ; 09]$

Chromosome[2] $=[\mathrm{a} ; \mathrm{b} ; \mathrm{c} ; \mathrm{d}]=[10 ; 02 ; 08 ; 05]$

Chromosome[3] $=[\mathrm{a} ; \mathrm{b} ; \mathrm{c} ; \mathrm{d}]=[25 ; 05 ; 07 ; 10]$

c. Evaluasi Chromosome

fungsi_objektif(chromosome[1])= $\operatorname{Abs}((15+$ $2 * 4+3 * 6+4 * 9)-30)$

$=\operatorname{Abs}((15+8+18+36)-30)$

$=\operatorname{Abs}(77-30)$

$=47$

fungsi_objektif $($ chromosome[2] $)=\operatorname{Abs}((10+$ $2 * 2+3 * 8+4 * 5)-30)$

$=\operatorname{Abs}((10+4+24+20)-30)$

$=\operatorname{Abs}(58-30)$

$=28$ 
Jurnal Pseudocode, Volume V Nomor 2, September 2018, ISSN 2355-5920

www.ejournal.unib.ac.id/index.php/pseudocode

fungsi_objektif(chromosome[3])=Abs $((25$

$2 * 5+3 * 7+4 * 10)-30)$

$=\operatorname{Abs}((25+10+21+40)-30)$

$=\operatorname{Abs}(96-30)$

$=66$

d. Seleksi Chromosome

Fitness $[1]=1 /($ fungsi_objektif $[1]+1)$

$$
=1 / 48
$$$$
=0,0208
$$

Fitness [2] = 1/(fungsi_objektif[2] +1$)$

$$
=1 / 29
$$$$
=0,0344
$$

Fitness [3] = 1/(fungsi_objektif[3] + 1)

$$
\begin{aligned}
& =1 / 67 \\
& =0,0149
\end{aligned}
$$

Total_Fitness $=0,0208+0,0344+0,0149$

$$
=0,0701
$$

e. Probabilitas

$$
\begin{aligned}
\mathrm{P}[1] & =0,0208 / 0,0701 \\
& =0,2967 \\
\mathrm{P}[1] & =0,0344 / 0,0701 \\
& =0,4907 \\
\mathrm{P}[1] & =0,0149 / 0,0701
\end{aligned}
$$

\section{HASIL DAN PEMBAHASAN}

\section{A. Hasil}

a. Tampilan Beranda

Tampilan beranda (Gambar 2) merupakan tampilan awal atau tampilan index dari aplikasi ini.

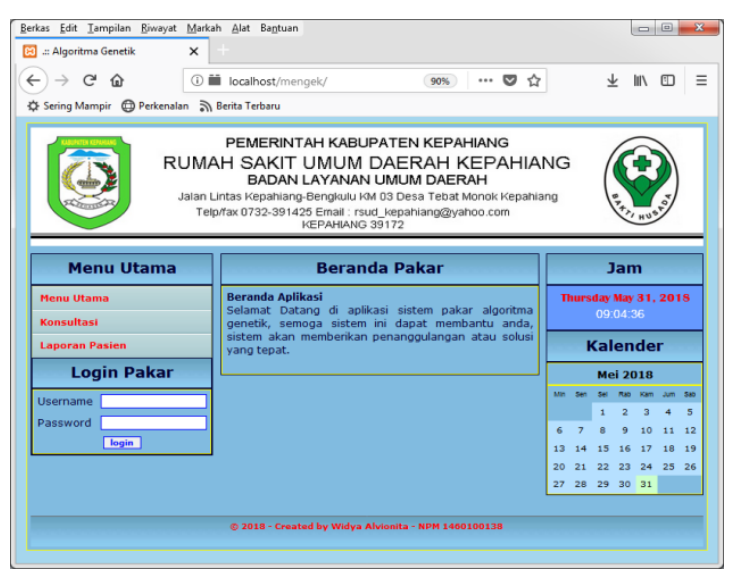

Gambar 2. Tampilan Beranda

b. Tampilan Konsultasi

Tampilan konsultasi (Gambar 3) merupakan tampilan checklist gejala dari penyakit tersebut.

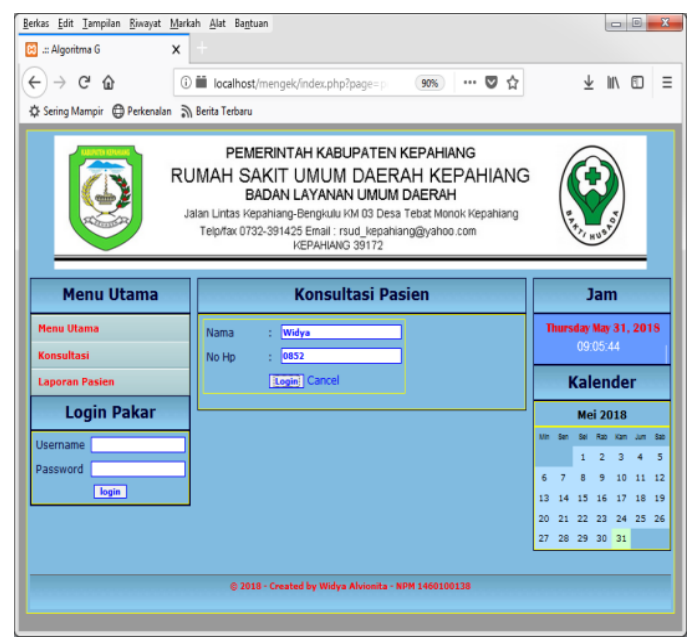

Gambar 3. Tampilan Konsultasi

c. Tampilan Hasil Konsultasi

Tampilan hasil konsultasi (Gambar 4) merupakan hasil perhitungan algoritme genetik, dengan memilih gejala akan menampilkan informasi penyakit, solusi, obat, dan penyebab dari penyakit ini.

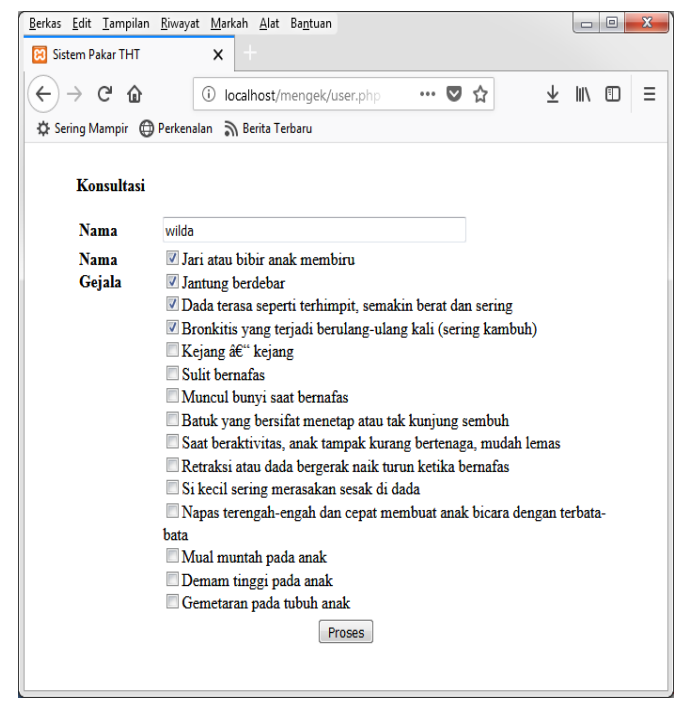

Gambar 4. Tampilan Hasil Konsultasi

d. Tampilan Cetak Hasil

Tampilan hasil cetak (Gambar 5) merupakan tampilan cetak dari konsultasi pasien secara langsung.

e. Tampilan Login Admin

Tampilan login (Gambar 6) merupakan sistem 
Jurnal Pseudocode, Volume V Nomor 2, September 2018, ISSN 2355-5920 www.ejournal.unib.ac.id/index.php/pseudocode

keamanan dalam aplikasi, sehingga aplikasi tidak bisa digunakan oleh siapapun kecuali administrator.

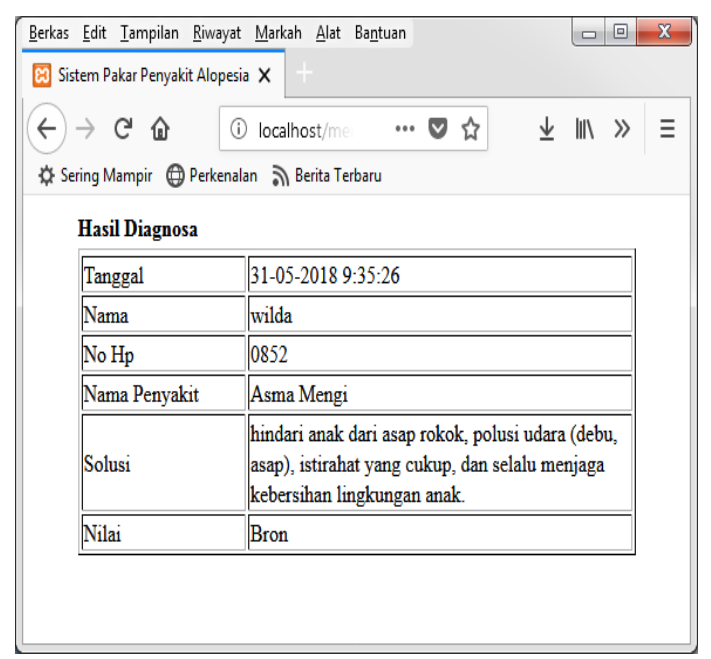

Gambar 5. Tampilan Hasil Cetak

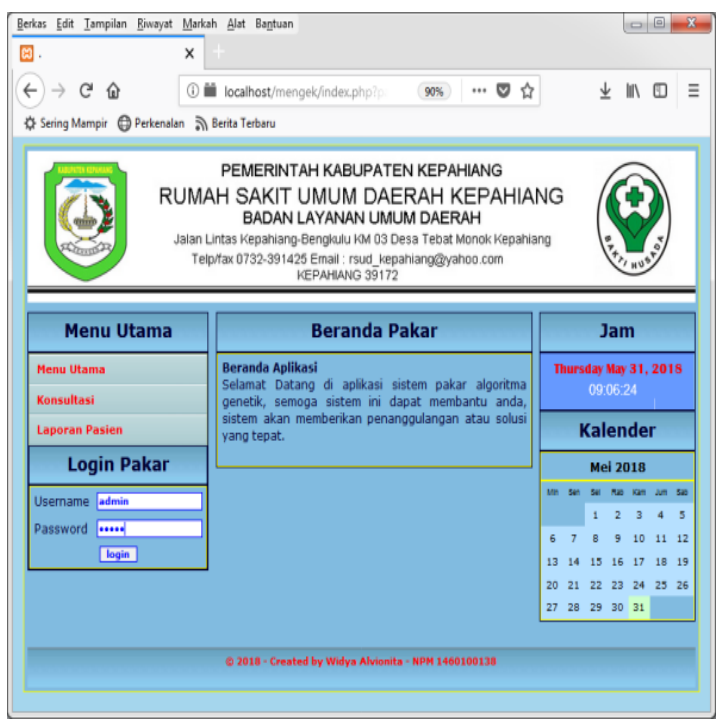

Gambar 6. Tampilan Login

\section{f. Tampilan Input Gejala}

Tampilan input data gejala (Gambar 7) merupakan tampilan input data gejala, berisikan id gejala dan nama gejala.

\section{g. Tampilan Input Penyakit}

Tampilan input data Penyakit merupakan tampilan input data Penyakit, berisikan id Penyakit, nama Penyakit, dan pengendalian. Adapun tampilan input data Penyakit dapat dilihat pada gambar Gambar 8.

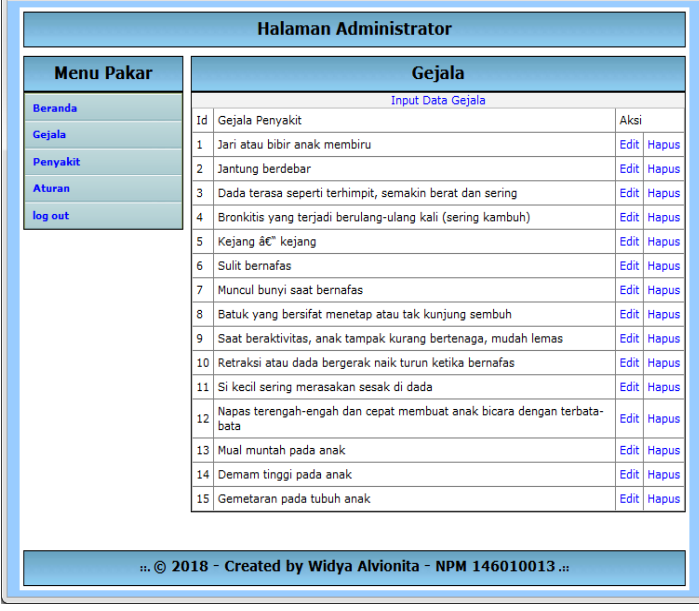

Gambar 7. Tampilan Input Data Gejala

\begin{tabular}{|c|c|c|c|}
\hline \multicolumn{4}{|c|}{ Halaman Administrator } \\
\hline Menu Pakar & \multicolumn{3}{|c|}{ Penyakit } \\
\hline Bernda & \multicolumn{3}{|c|}{ Input Data Penyakt } \\
\hline \multirow{2}{*}{ Gejala } & Id & Nama Penyakt & Aksi \\
\hline & 1 & Asma Nengi & Edt hapus \\
\hline Penyakit & 2 & Asma Patogenesis & Edt Hapus \\
\hline Aturan & 3 & Asma Sensitisas & Edt Hapus \\
\hline \multicolumn{4}{|l|}{$\log$ out } \\
\hline & & ed by Widya A. & \\
\hline
\end{tabular}

Gambar 8. Tampilan Input Data Penyakit

h. Tampilan Basis Pengetahuan

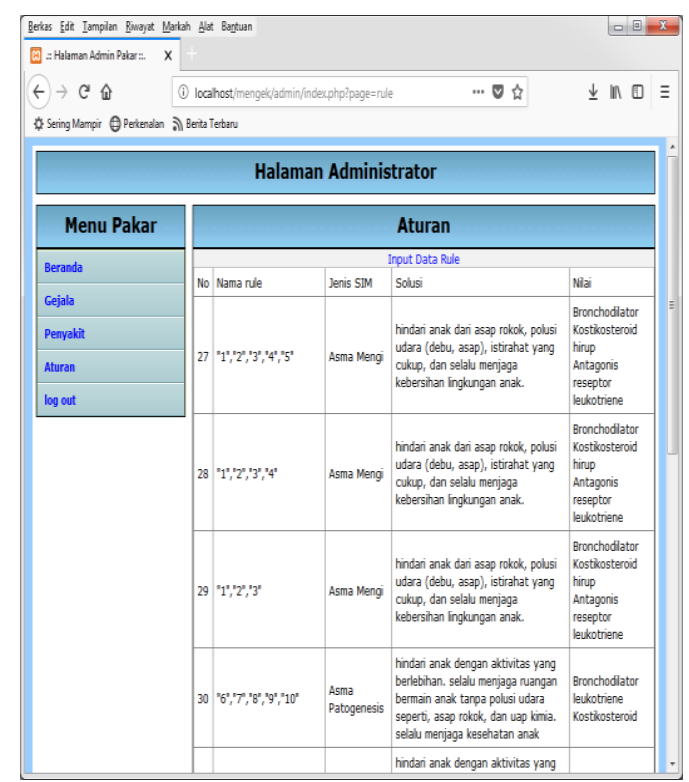

Gambar 9. Tampilan Input Data Pengetahuan 
Jurnal Pseudocode, Volume V Nomor 2, September 2018, ISSN 2355-5920

www.ejournal.unib.ac.id/index.php/pseudocode

\section{B. Pembahasan}

a. Black Box

Tabel 5. Pengujian Black Box

\begin{tabular}{|c|c|c|}
\hline $\begin{array}{l}\text { Aktifitas } \\
\text { Pengujian }\end{array}$ & Realisasi yang diharapkan & Hasil \\
\hline $\begin{array}{l}\text { Menu } \\
\text { Beranda }\end{array}$ & $\begin{array}{l}\text { Informasi Tampilan menu } \\
\text { dalam aplikasi }\end{array}$ & $\begin{array}{l}\text { Sukses } \\
\text { (Gambar 2) }\end{array}$ \\
\hline $\begin{array}{l}\text { Menu } \\
\text { Konsultasi }\end{array}$ & $\begin{array}{l}\text { Menampilkan informasi } \\
\text { gejala penyakit mengik }\end{array}$ & $\begin{array}{l}\text { Sukses } \\
\text { (Gambar 3) }\end{array}$ \\
\hline $\begin{array}{l}\text { Hasil } \\
\text { Konsultasi }\end{array}$ & 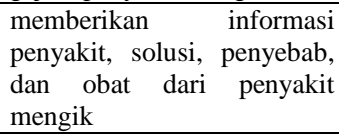 & $\begin{array}{l}\text { Sukses } \\
\text { (Gambar 4) }\end{array}$ \\
\hline $\begin{array}{l}\text { Tampilan } \\
\text { Hasil Cetak }\end{array}$ & $\begin{array}{l}\text { Tampilan untuk melihat } \\
\text { hasil konsultasi }\end{array}$ & $\begin{array}{l}\text { Sukses } \\
\text { (Gambar 5) }\end{array}$ \\
\hline Login & $\begin{array}{ll}\text { Tampilan } & \text { Informasi } \\
\text { username dan } & \text { password } \\
\text { administrator } & \\
\end{array}$ & $\begin{array}{l}\text { Sukses } \\
\text { (Gambar 6) }\end{array}$ \\
\hline Input Gejala & Informasi Input Data Gejala & $\begin{array}{l}\text { Sukses } \\
\text { (Gambar 7) }\end{array}$ \\
\hline $\begin{array}{l}\text { Input } \\
\text { Penyakit }\end{array}$ & $\begin{array}{l}\text { Informasi Input } \\
\text { Penyakit }\end{array}$ & $\begin{array}{l}\text { Sukses } \\
(\text { Gambar 8) }\end{array}$ \\
\hline $\begin{array}{l}\text { Input } \\
\text { Pengetahuan }\end{array}$ & $\begin{array}{ll}\text { Informasi } & \text { Input } \\
\text { Pengetahuan } & \\
\end{array}$ & $\begin{array}{l}\text { Sukses } \\
\text { (Gambar 9) }\end{array}$ \\
\hline
\end{tabular}

b. Hasil Pengujian

Tabel 6. Hasil Pengujian

\begin{tabular}{|c|l|c|c|c|}
\hline \multirow{2}{*}{ No } & \multicolumn{1}{|c|}{ Kriteria } & \multicolumn{3}{|c|}{ Persentase \% } \\
\cline { 3 - 5 } & SM & M & TM \\
\hline 1 & $\begin{array}{l}\text { Program bersifat Interaktif } \\
\text { dan Dinamis }\end{array}$ & 15 & 4 & 1 \\
\hline 2 & Aplikasi membantu & 16 & 4 & 0 \\
\hline 3 & $\begin{array}{l}\text { Bagaimana penerapan } \\
\text { algoritme genetika sesuai } \\
\text { dengan kebutuhan sistem }\end{array}$ & 5 & 14 & 1 \\
\hline 4 & Warna tampilan menarik & 5 & 10 & 5 \\
\hline 5 & $\begin{array}{l}\text { Menu tampilan bersifat } \text { user } \\
\text { friendly }\end{array}$ & 6 & 13 & 1 \\
\hline \multicolumn{4}{|c|}{ Jumlah Responden } & \multicolumn{3}{|c|}{20} \\
\hline
\end{tabular}

Maka diperoleh jawaban sangat menarik 47 \%, menarik $45 \%$, dan tidak menarik $8 \%$. Adapun cara perhitungannya adalah sebagai berikut:

1. Hitung setiap row pernyataan kemudian pernyataan dijumlahkan.

2. Lakukan penghitungan

a. 1. Sangat Menarik

$$
\frac{47}{100} \times 100=47 \%
$$

b. 2. Menarik

$$
\frac{45}{100} \times 100=45 \%
$$

c. 3. Tidak Menarik

$$
\frac{8}{100} \times 100=8 \%
$$

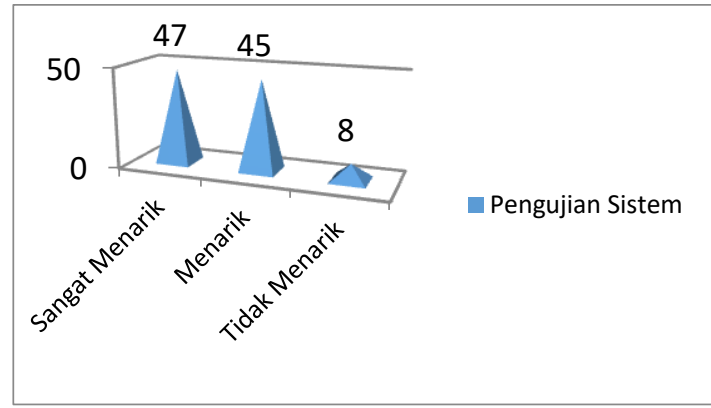

Gambar 10. Hasil Pengujian

\section{KESIMPULAN DAN SARAN}

\section{A. Kesimpulan}

Berdasarkan hasil pengujian yang telah dapat disimpulkan sebagai berikut:

1. Dari hasil pengujian sistem diperoleh jawaban sangat menarik $47 \%$, menarik $45 \%$, dan tidak menarik $\mathbf{8 \%}$.

2. Secara umum, untuk jumlah titik yang kecil solusi yang dihasilkan algoritme genetika mempunyai kualitas lebih baik. Algoritme genetika dapat memberikan solusi mendekati optimal, Secara umum, untuk jumlah titik yang kecil solusi yang dihasilkan algoritme genetika mempunyai kualitas lebih baik. Algoritme genetika dapat memberikan solusi mendekati optimal.

3. Durasi waktu proses perhitungan pada algoritme genetika kurang efisien.

\section{B. Saran}

Dikarenakan ilmu pengetahuan terus berkembang dan ditemukannya hal-hal baru maka basis pengetahuan dan basis aturan sistem pendukung keputusan ini perlu di-update atau ditambah, sehingga data-data yang ada menjadi lebih lengkap dan akurat. Interface (tampilan) sistem yang dibangun masih tampak sederhana, sehingga dapat dikembangkan lebih menarik. 
Jurnal Pseudocode, Volume V Nomor 2, September 2018, ISSN 2355-5920

www.ejournal.unib.ac.id/index.php/pseudocode

\section{REFERENSI}

[1] Rachmawat, Dhani Johar Damir, Ate Susanto, 2012, “ Sistem Pakar Diagnosis Penyakit Asma “ , Jurnal Algoritme No. 08 Vol 09 ISSN : 2302-7339.

[2] Kurniawan B. Rubby, 2013 “ Aplikasi Algoritme Genetika Untuk Optimasi Penjadwalan Perkulihan (Genetika Algoritme Aplication For Optimization Of Activities Schedul), Jurnal Tranformatika Volume 6 Nomor I, Semarang.

[2] Swono Sibagariang, 2015 “ Sistem Pakar Diagnosis Penyakit Sapi dengan Metode Certainty Factor Berbasis Android ", Jurnal TIMES, No 2, Vol IV, ISSN : 23373601.
[3] Pedianti Sari, 2002, " Asma pada Anak “ No.2, Vol. 4, $2002: 7882$

[4] Saniman, Fahtoni Muhammad, 2008 " Algoritme dan Pemrograman,Jurnal SAINTIKOM, No.4 Vol. IV.

[5] Elya Nusantra, 2013," JenisMiskonsepi Genetika yang Ditemukan pada Buku Ajar diSekolah Menengah Atas “, Jurnal Pendidikan Sains, No. 1 Vol. 1.

[6] Rosa A.S dan Salahuddin M, 2011. “ Pembelajaran Rekayasa Perangkat Lunak (Terstruktur dan Berorientasi Objek)," Informatika, Bandung. 